\title{
Yield and Aging of Cheddar Cheeses Manufactured from Milks with Different Milk Serum Protein Contents*
}

\author{
B. K. Nelson and D. M. Barbano \\ Northeast Dairy Foods Research Center, Department of Food Science, \\ Cornell University, Ithaca, NY 14853
}

\begin{abstract}
Whey proteins in general and specifically $\beta$-lactoglobulin, $\alpha$-lactalbumin, and immunoglobulins have been thought to decrease proteolysis in cheeses manufactured from concentrated retentates from ultrafiltration. The proteins found in whey are called whey proteins and are called milk serum proteins (SP) when they are in milk. The experiment included 3 treatments; low milk SP $(0.18 \%)$, control $(0.52 \%)$, and high milk SP $(0.63 \%)$, and was replicated 3 times. The standardized milk for cheese making of the low milk SP treatment contained more casein as a percentage of true protein and more calcium as a percentage of crude protein, whereas the nonprotein nitrogen and total calcium content was not different from the control and high SP treatments. The nonprotein nitrogen and total calcium content of the milks did not differ because of the process used to remove the milk SP from skim milk. The low milk SP milk contained less free fatty acids (FFA) than the control and high milk SP treatment; however, no differences in FFA content of the cheeses was detected. Approximately 40 to $45 \%$ of the FFA found in the milk before cheese making was lost into the whey during cheese making. Decreasing the milk SP content of milk by $65 \%$ and increasing the content by $21 \%$ did not significantly influence general Cheddar cheese composition. Higher fat recovery and cheese yield were detected in the low milk SP treatment cheeses. There was more proteolysis in the low milk SP cheese and this may be due to the lower concentration of undenatured $\beta$ lactoglobulin, $\alpha$-lactalbumin, and other high molecular weight SP retained in the cheeses made from milk with low milk SP content.
\end{abstract}

(Key words: serum protein, cheese, yield, proteolysis)

Received May 7, 2005.

Accepted May 31, 2005.

Corresponding author: David M. Barbano; e-mail: dmb37@ cornell.edu.

*Use of names, names of ingredients, and identification of specific models of equipment is for scientific clarity and does not constitute any endorsement of product by authors, Cornell University, or the Northeast Dairy Foods Research Center.
Abbreviation key: $\mathbf{D F}=$ diafiltration, $\mathbf{M F}=$ microfiltration, $\mathbf{R M F}=$ retentate from microfiltration, SNPTN = soluble nitrogen as a percentage of total nitrogen, $\mathbf{S P}=$ serum protein, $\mathbf{S P C}=$ serum protein concentrate, $\mathbf{T N}=$ total nitrogen.

\section{INTRODUCTION}

Native $\beta$-LG inhibits the proteolysis of $\mathrm{CN}$ by plasmin more so than denatured $\beta$-LG (Bastian et al., 1993). Native and denatured $\beta$-LG inhibited chymosin hydrolysis of $\alpha_{\mathrm{s} 1}-\mathrm{CN}$ in simulated milk ultrafiltrate (Lo and Bastian, 1997). Denatured $\alpha$-LA inhibited chymosin activity on $\alpha_{\mathrm{s} 1}-\mathrm{CN}$ in simulated milk ultrafiltrate (Lo and Bastian, 1997). Whey proteins present in cheese made from milk with moderate or no heat treatment would be in solution in the water phase of the cheese. Nelson et al. (2004b) reported that whey proteins are present in the expressible serum of Cheddar cheese. Slower proteolysis during aging in Cheddar cheese manufactured from concentrated UF retentates has been well documented (Covacevich and Kosikowsi, 1978; Creamer, 1987). Lelievre et al. (1990) reported that other high molecular weight whey proteins (e.g., immunoglobulins) inhibit proteolysis of $\alpha_{\mathrm{s} 1}-\mathrm{CN}$ by rennet. Akaeda et al. (1971) reported that $\alpha_{2}$-macroglobulin bound directly to $\kappa$-CN and decreased rennin activity. Plasmin is also inhibited by the large molecular weight proteins $\alpha_{2}$-macroglobulin (Steiner et al., 1987) and $\alpha_{2}$ antiplasmin (Precetti et al., 1997). Higher whey protein retention in cheeses was attractive with respect to increasing cheese yield, but the decreased proteolysis accompanying higher whey protein retention was detrimental to Cheddar cheese flavor development. Cheddar cheese made from unconcentrated milk usually contains very little whey protein (O'Keeffe et al., 1978), generally $<1 \%$ of the cheese protein, and yet whey proteins comprise most of the protein in the expressible serum of these cheeses (Nelson et al., 2004b). The water phase of cheeses manufactured from concentrated retentates from UF would contain even more whey proteins. Therefore, one could hypothesize that reducing protease inhibitors in the water phase of cheese could increase the rate of $\mathrm{CN}$ proteolysis, and potentially in- 
crease the rate of development of typical Cheddar flavors.

Microfiltration (MF) enables $\beta$-LG and $\alpha$-LA to be separated from CN in skim milk. Cheddar cheeses manufactured from low concentration factor retentate from microfiltration (RMF; 1.2 to $1.8 \times$ ) had lower soluble nitrogen as a percentage of total nitrogen (SNPTN) and less CN degradation over $180 \mathrm{~d}$ of aging (Neocleous et al., 2002b). By adjusting the moisture-in-the-nonfat substance of cheese from the $1.8 \times$ treatment to the same level as the control and adding more chymosin (Neocleous et al., 2002b), the cheese SNPTN and CN degradation increased to a level similar to that of the control cheese. Neocleous et al. (2002b) indicated, as have others, that large molecular weight proteins retained in cheese might reduce chymosin and plasmin activity (Akaeda et al., 1971; Steiner et al., 1987; Lelievre et al., 1990; Precetti et al., 1997). Milk minus milkfat is called milk plasma, whereas milk plasma minus CN micelles is called milk serum. Milk serum proteins (SP) are largely present in milk serum in molecular form or as very small aggregates (Walstra et al., 1999). Because the milk SP concentration in the standardized milks of Neocleous et al. (2002a) increased (0.52 to $0.59 \%$ ) with increasing concentration factor (1.2 to $1.8 \times$ ), they concluded that large molecular weight milk SP may be retained by the MF membrane. The work of Jost et al. (1999) supports their conclusion that immunoglobulins are retained by a $0.1-\mu \mathrm{m}$ MF membrane.

Recently, a diafiltration (DF) process was reported to remove $95 \%$ of the milk SP, mostly $\beta$-LG and $\alpha$-LA, from skim milk (Nelson and Barbano, 2005). Milk SP are whey proteins that have been removed from milk before the cheese making process and are therefore not part of the whey. We are unaware of any studies that measured the yield and proteolysis of Cheddar cheese from milk with $95 \%$ of the milk SP removed before cheese making. In this experiment, we removed about 95\% of the milk SP from the skim milk before standardizing with cream so that the direct impact of variation in milk SP on cheese proteolysis could be determined. We hypothesize that removing milk SP from milk before cheese making should increase proteolysis but have little or no detectable influence on cheese yield in cheeses with the lower milk SP content.

\section{MATERIALS AND METHODS}

\section{Milk Processing}

One batch of whole milk was pasteurized $\left(72^{\circ} \mathrm{C}\right.$ for $15 \mathrm{~s})$ then separated into cream and skim milk using a centrifugal separator. The skim milk was divided into 3 portions: 1 to be used for a low milk SP treatment, 1 for an high milk SP treatment, and 1 to be used for a control with typical milk SP content. A 3-stage process with $1 \mathrm{MF}$ stage $(0.1 \mu \mathrm{m}$ pore size, $3 \times$ concentration factor) and $2 \mathrm{DF}$ stages was used to remove SP from skim milk for the low milk SP treatment and produce the serum protein concentrate (SPC) for the high milk SP treatment, as described by Nelson and Barbano (2005). Permeate from the UF of the permeate from MF was used as the diafiltrant instead of water so that the lactose, NPN, and calcium concentrations in the milk with decreased SP content would remain the same as the original milk (Nelson and Barbano, 2005). The $3 \times$ MF skim retentate from the third stage of the process was diluted with permeate from UF to reduce the casein concentration back to the level in the original skim milk. To determine the amount of dilution needed, the true protein content of the diluted retentate and original skim milk was measured using a MilkoScan 605 infrared milk analyzer (A/S Foss Electric, Hillerød, Denmark). The CN content of the RMF was estimated $(0.82 \times$ true protein) from the infrared results. The diluted diafiltered RMF was stored overnight at $4^{\circ} \mathrm{C}$ before cheese making.

The low milk SP standardized milk was made by combining diluted diafiltered RMF with cream. The control standardized milk was made by combining skim milk and cream. The high milk SP standardized milk was made by combining skim milk with cream and then adding milk SPC (about $3.2 \mathrm{~kg}$ ) containing about $10 \%$ milk SP. The milk SPC was made by concentrating permeate from the MF of skim milk using UF (Nelson and Barbano, 2005).

\section{Cheese Manufacture}

An 18-kg block of Cheddar cheese was manufactured from each of the 3 treatment milks on the day after MF processing. All weights were measured to the nearest gram (model SB32000, Mettler Toledo Instrument Co., Highstone, NJ) for mass balance calculations. Cheeses were manufactured according to the procedure described by Nelson et al. (2004a) with the following exceptions: starter usage rate $=0.2 \mathrm{~g} / \mathrm{kg}$ of milk; whey draining $\mathrm{pH}=6.40$; and the salting rate was $3 \%$ of the curd weight. The MF processing and cheese making was replicated 3 times in a 3 -wk period using 3 different batches of milk.

\section{Milk, Whey, Salt Whey, and Cheese Sampling}

Raw whole milk was mixed, sampled at $4^{\circ} \mathrm{C}$ before pasteurization, and tested for SCC. Milks for cheese making were sampled at $31^{\circ} \mathrm{C}$ immediately before starter addition. All of the whey drained from each cheese vat up to the time of salting was collected sepa- 
rately, heated to $38^{\circ} \mathrm{C}$, and mixed to obtain a representative sample. Once salting was initiated, the whey expressed from the curd during salting was collected separately. Salted curds were placed in 18-kg Wilson hoops. The press whey was collected by placing each Wilson hoop into a large 8-mil plastic bag (model number S-5851, Uline, Waukegan, IL) before pressing. After pressing, all of the whey was removed from each bag, and then hot water was run over the outside of each bag to melt and facilitate the removal of solidified fat from the inside of the bag. In this paper, salt whey refers to the mixture of the salt whey collected during salting of the milled curd plus the whey from pressing for each treatment.

Liquid samples were placed in 59-mL snap lid vials (Capital Vial, Inc., Fultonville, NY) and analyzed fresh or stored frozen at $-40^{\circ} \mathrm{C}$. Frozen samples were thawed in a microwave oven in a manner that kept the sample temperature below $10^{\circ} \mathrm{C}$. Thawed liquid samples were analyzed immediately. A 1-cm thick slice of cheese was cut from the center of each 18-kg block of cheese. Cheese slices were cut into $2-\mathrm{cm}$ pieces, ground (model 31BL92, Waring, New Hartford, CT), and packed into 59-mL snap lid vials with no headspace and either analyzed fresh or held frozen at $-40^{\circ} \mathrm{C}$. Frozen cheese samples were thawed overnight at $4^{\circ} \mathrm{C}$ before analysis.

\section{Microbiological Analyses of Milk}

Standard plate and total coliform counts of pasteurized whole milks were determined (Wehr and Frank, 2004; 6.020 and 7.020). Milk SCC was determined using a fluorimetric method (AOAC, 2000; 17.13.01, 978.26) on a MilkoScan Combi 4000 (A/S Foss Electric,) by a licensed (New York State) commercial laboratory (Dairy One, Ithaca, NY).

\section{Chemical Analyses}

Milk, whey, and salt whey composition. Fat, TS, total nitrogen (TN), NPN of milk, whey, and salt whey were determined using ether extraction (AOAC, 2000; 33.2.26, 989.05), forced air oven drying (AOAC, 2000; 33.2.44, 990.20), Kjeldahl (AOAC, 2000; 33.2.11, 991.20), and Kjeldahl (AOAC, 2000; 33.2.12, 991.21) respectively. Noncasein nitrogen content of milk was determined using the Kjeldahl method (AOAC, 2000; 33.2.64, 998.05). Crude protein, NPN, and noncasein N results were expressed as protein (nitrogen $\times 6.38$ ). The calcium content was determined using atomic absorption (Metzger et al., 2000). The Volhard method (Wehr and Frank, 2004; 15.052) was used to determine the salt content in the salt whey, using a 0.5 -g test portion. The FFA contents of cheeses were determined using a copper soap method (Ma et al., 2003). Free fatty acid results were expressed as milligrams per 100 grams so that total recovery of FFA in the cheese making process could be determined. Milk, whey, and salt whey compositions were determined in duplicate with the exception of TN, which was analyzed in triplicate. The SDS-PAGE method of Verdi et al. (1987) was used to verify the differences in milk SP content of the milks except that a gel with $15 \%$ acrylamide concentration was used.

Cheese composition and $\mathrm{pH}$. Cheese samples were taken immediately after the cheeses were finished pressing and at 30,90, and $180 \mathrm{~d}$ of refrigerated storage $\left(6^{\circ} \mathrm{C}\right)$. Fat content was determined using the Babcock method (Wehr and Frank, 2004; 15.083). Cheese moisture was determined gravimetrically by drying $2 \mathrm{~g}$ of cheese in a forced-air oven at $100^{\circ} \mathrm{C}$ for $24 \mathrm{~h}$ (AOAC, $2000 ; 33.2 .44,990.20$ ). Salt content was determined using the Volhard method (Wehr and Frank, 2004; 15.052). The Kjeldahl method ( $1 \mathrm{~g}$ of cheese) was used to determine CP (Lynch et al., 2002). Total calcium content was determined by atomic absorption (Metzger et al., 2000). Cheese FFA content was determined using a copper soap method (Melilli et al., 2004). Cheese $\mathrm{pH}$ was measured using a Xerolyt combination electrode (model HA405; Mettler Toledo, Columbus, $\mathrm{OH}$ ) and an Accumet $\mathrm{pH}$ meter (model AR 25, Fisher Scientific, Pittsburgh, PA) after tempering to $23^{\circ} \mathrm{C}$. Moisture and fat analyses were performed in quadruplicate, TN in triplicate, and all other analyses in duplicate.

Cheese proteolysis. Indices of proteolysis in the cheeses were also measured at $0,30,90$, and $180 \mathrm{~d}$ of refrigerated storage at $6^{\circ} \mathrm{C}$. Cheese $\mathrm{pH} 4.6$ and $12 \%$ TCA SNPTN were determined in duplicate (Bynum and Barbano, 1985). Proteolysis of $\alpha_{\mathrm{s}}-\mathrm{CN}$ and $\beta$-CN were measured using SDS-PAGE (Nelson et al., 2004b).

\section{Component Recoveries, Cheese Yield, and Yield Efficiency}

Recoveries of fat, $\mathrm{CP}$, calcium, total milk solids, and FFA were calculated using the weights (in grams) and compositions of milk, whey, salt whey, and cheese. Total milk solids recovery did not include the added salt $(\mathrm{NaCl})$ or the salt $(\mathrm{NaCl})$ content of the salt whey and cheese. If the mean total unadjusted recoveries were not significantly different $(P>0.05)$ among treatments, then the recoveries were adjusted by dividing the actual recoveries by the mean total recovery for each day of cheese making and multiplying by 100 . Actual, moisture and salt-adjusted theoretical yields, and cheese yield efficiencies were calculated as described in Nelson et al. (2004a). 
Table 1. Mean $(n=3)$ compositions of the low, control, and high milk serum protein (SP) standardized milks for Cheddar cheese manufacture.

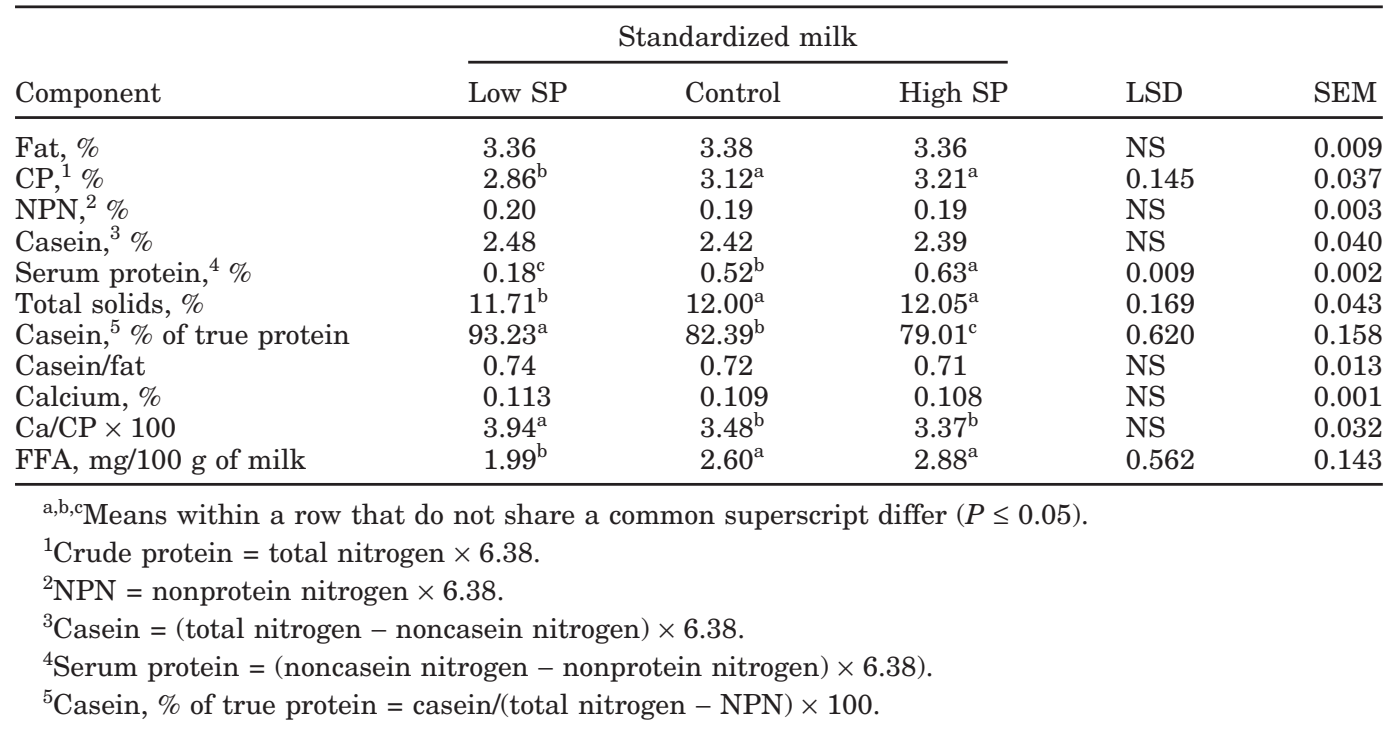

\section{Statistical Analyses}

There were 3 treatments (low, control, and high milk SP levels) that were category variables. All data were analyzed using ANOVA. If the $F$-test for the statistical model was significant, then the least significant difference test $(P \leq 0.05)$ was used to compare the treatments for composition, make times, component recovery, and yield. Data collected during cheese aging (i.e., $\mathrm{pH}$, titratable acidity, FFA, SNPTN, and CN:para- $\kappa$-CN) were analyzed using a split-plot model. Treatment was the whole plot, cheese age was the subplot, and replicate (i.e., week of cheese making) was blocked. The interaction of treatment by replicate was used as the whole plot error term. Cheese age was treated as a continuous variable and was transformed as described in Nelson et al. (2004b) to minimize the multicollinearity of the linear and quadratic forms of the age variable (Glantz and Slinker, 2001). All statistical analyses were done using the PROC GLM procedure of SAS (SAS version 8.02, 1999-2001, SAS Institute Inc., Cary, NC).

\section{RESULTS AND DISCUSSION}

\section{Milk Composition and Cheese Manufacturing}

The mean SCC of the raw milks was 259,000 cells/ $\mathrm{mL}$. The mean standard plate count for the standardized milks of each treatment were $<8000 \mathrm{cfu} / \mathrm{mL}$. The DF process, using permeate from ultrafiltration as the diafiltrant, kept the NPN and calcium content of the standardized milks the same among treatments (Table 1) while decreasing the milk SP content (Figure 1). This would not have been possible if water was used as the diafiltrant. Although lactose was not measured directly, the total solids minus fat and CP is mostly lactose and this difference was similar among treatments. The concentrations of low molecular weight nitrogen components (i.e., NPN) and energy sources for the starter culture were similar among treatments. Using permeate from ultrafiltration as a diafiltrant produced normal milk coagulation during cheese making for the low milk SP treatment because the unbound calcium content of the standardized milk was similar to the control and high milk SP treatment. In contrast, if water were used for DF, added calcium would be needed for normal milk coagulation. The $\mathrm{CN}$ contents of the standardized milks were not significantly different, but when the $\mathrm{CN}$ content was expressed as a percentage of true protein, there were significant $(P \leq 0.05)$ differences among the 3 treatments (Table 1). The CN as a percentage of true protein in the low milk SP treatment was almost $11 \%$ higher than the control and over 14\% higher than the high milk SP treatment. Calcium expressed as a percentage of $\mathrm{CP}$ was higher $(P \leq 0.05)$ for the low milk SP milk than control or high milk SP milk (Table 1). This was expected as CN as a percentage of true protein increased.

There were no significant differences $(P>0.05)$ in fat content or CN-to-fat ratio among the standardized milks. A lower $(P \leq 0.05) \mathrm{FFA}$ content in the low milk SP standardized milk was detected but not expected (Table 1). Fatty acid binding by $\beta$-LG has been reported (Pérez et al., 1989). The lower concentration of FFA in the low milk SP standardized milk may have been a result of removing the FFA bound to $\beta$-LG during MF. Moreover, the higher mean FFA concentration of the 


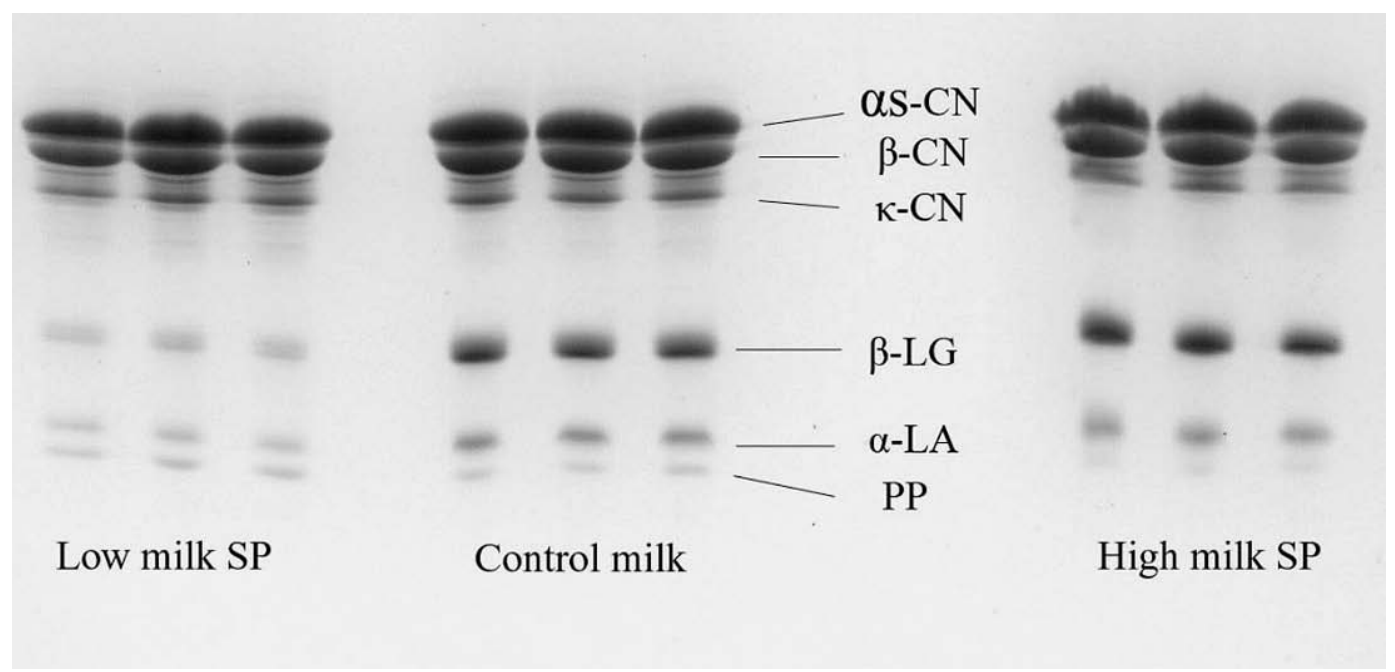

Figure 1. Proteins in the standardized milks from each of the 3 replicates separated by SDS-PAGE. PP = proteolysis product.

high milk SP standardized milk may be due to the fatty acids-associated $\beta$-LG that were added as part of the milk SPC. It is likely that the mean FFA content of the high milk SP treatment would have been significantly higher than the control if we had added more milk SPC to the high milk SP treatment.

The 3 treatments did not differ $(P>0.05)$ in $\mathrm{pH}$ before culture addition, at whey draining, or at milling (Table 2). A small difference (0.03) in $\mathrm{pH}$ between the low milk SP treatment and high milk SP treatment was detected at the time of coagulant addition (Table 2). No significant difference in make time was found among the 3 treatments (Table 3).

\section{Whey, Salt Whey, and Cheese Composition}

The whey from the low milk SP treatment contained less fat than the control and high milk SP treatments (Table 4). As expected, the low milk SP treatment contained less $\mathrm{CP}(P \leq 0.05)$ and whey proteins than control and high milk SP treatment because milk SP, which become whey proteins during cheese making, were removed before cheese manufacture (Table 4). The whey from the low milk SP treatment contained less calcium $(P \leq 0.05)$ and FFA than the control or high milk SP treatment. Removing milk SP from milk before cheese making also removed fatty acids bound to $\beta$-LG; therefore, the whey FFA content was lower because of the lower SP content. Whey protein was the only component of salt whey that differed $(P \leq 0.05)$ among the three treatments. Decreasing standardized milk SP content by $65 \%$ and increasing milk SP content by $21 \%$ did not change Cheddar cheese composition (Table 4). Cheese manufacturers that remove SP from milk by the MF process described by Nelson and Barbano (2005) before cheese making can do so without significantly changing their cheese composition.

\section{Component Recoveries and Cheese Yield}

The mean total unadjusted recoveries were 99.32, 99.13, $99.13 \%$ for milk solids; $98.35,97.74,96.68 \%$ for

Table 2. Mean $(\mathrm{n}=3) \mathrm{pH}$ during the manufacture of Cheddar cheese from low, control, and high milk serum protein (SP) standardized milks. ${ }^{1}$

\begin{tabular}{llllll}
\hline & \multicolumn{3}{c}{ Standardized milk } & \\
\cline { 2 - 5 } & Low SP & Control & High SP & LSD & SEM \\
\hline Milk & 6.68 & 6.68 & 6.67 & NS & 0.007 \\
Coagulant addition $^{2}$ & $6.65^{\mathrm{a}}$ & $6.63^{\mathrm{ab}}$ & $6.62^{\mathrm{b}}$ & 0.015 & 0.004 \\
Whey at draining $_{\text {Curd at milling }}^{6.40}$ & 5.30 & 6.40 & 6.39 & NS & 0.006 \\
\hline
\end{tabular}

${ }^{\mathrm{a}, \mathrm{b}}$ Means within a row that do not share a common superscript differ $(P \leq 0.05)$.

${ }^{1} \mathrm{pH}$ measured at $31^{\circ} \mathrm{C}$ for milk and $38^{\circ} \mathrm{C}$ for whey and curd.

${ }^{2}$ Ripened (45 min) milk sample. 
Table 3. Mean $(n=3)$ make times (in minutes) for Cheddar cheeses manufactured from low, control, and high milk serum protein (SP) standardized milks.

\begin{tabular}{llllllr}
\hline & \multicolumn{3}{c}{ Standardized milk } & & \\
\cline { 2 - 4 } & Low SP & Control & High SP & LSD & SEM \\
\hline Coagulant addition to whey draining & 101 & 105 & 107 & NS & 3 \\
Whey draining to curd milling & 133 & 143 & 122 & NS & 12 \\
Total & 234 & 248 & 229 & NS & 12 \\
Stir out & 24 & 27 & 28 & NS & 2 \\
\hline
\end{tabular}

fat; 99.91, 99.72, 99.80\% for CP; 99.96, 101.67, $101.61 \%$ for calcium; $120.19,100.68,104.57 \%$ for FFA, respectively, in the low milk SP, control, and high milk SP treatments. No significant difference in total accountability of milk solids, fat, CP, calcium, or FFA was detected $(P>0.05)$ due to milk SP content. Mean total recoveries were adjusted as described by Nelson et al. (2004a).
The low SP treatment (SP reduced by $65 \%$ ) in the current study had lower fat recovery in the whey and higher fat recovery in the cheese (Table 5), compared with the control. The higher milk SP treatment (SP increased by $21 \%$ ) did not seem to significantly affect fat recovery in the whey or cheese. Lower fat recovery in control cheese has been observed previously in our laboratory when skim and cream (obtained from milk

Table 4. Mean $(\mathrm{n}=3)$ whey, salt whey, and cheese composition from the manufacture of cheeses from control, low, and high milk serum protein (SP) standardized milks.

\begin{tabular}{|c|c|c|c|c|c|}
\hline & \multicolumn{3}{|c|}{ Standardized milk } & \multirow[b]{2}{*}{ LSD } & \multirow[b]{2}{*}{ SEM } \\
\hline & Low SP & Control & High SP & & \\
\hline \multicolumn{6}{|l|}{ Whey } \\
\hline Fat, $\%$ & $0.29^{b}$ & $0.32^{\mathrm{a}}$ & $0.31^{\mathrm{a}}$ & 0.016 & 0.004 \\
\hline $\mathrm{CP}, \%$ & $0.51^{\mathrm{c}}$ & $0.92^{\mathrm{b}}$ & $1.04^{\mathrm{a}}$ & 0.019 & 0.005 \\
\hline $\mathrm{NPN}^{1} \%$ & 0.27 & 0.25 & 0.26 & NS & 0.006 \\
\hline Whey protein ${ }^{2} \%$ & $0.24^{\mathrm{c}}$ & $0.66^{\mathrm{b}}$ & $0.78^{\mathrm{a}}$ & 0.027 & 0.007 \\
\hline Total solids, \% & $6.41^{\mathrm{c}}$ & $6.89^{\mathrm{b}}$ & $7.02^{\mathrm{a}}$ & 0.072 & 0.018 \\
\hline Calcium, \% & $0.038^{\mathrm{b}}$ & $0.041^{\mathrm{a}}$ & $0.041^{\mathrm{a}}$ & 0.002 & 0.0004 \\
\hline FFA, mg/100 $\mathrm{g}$ of whey & $1.08^{\mathrm{b}}$ & $1.28^{\mathrm{a}}$ & $1.40^{\mathrm{a}}$ & 0.127 & 0.032 \\
\hline \multicolumn{6}{|l|}{ Salt whey (SW) } \\
\hline Fat, \% & 1.23 & 2.21 & 1.75 & NS & 0.243 \\
\hline $\mathrm{CP}, \%$ & $0.90^{\mathrm{b}}$ & $1.16^{\mathrm{a}}$ & $1.23^{\mathrm{a}}$ & 0.131 & 0.033 \\
\hline NPN, \% & 0.47 & 0.43 & 0.40 & NS & 0.018 \\
\hline Whey protein, \% & $0.44^{\mathrm{c}}$ & $0.73^{\mathrm{b}}$ & $0.82^{\mathrm{a}}$ & 0.063 & 0.016 \\
\hline Total solids, \% & 18.89 & 18.09 & 18.53 & NS & 0.877 \\
\hline Salt, \% & 9.91 & 9.19 & 9.68 & NS & 0.274 \\
\hline Calcium, \% & 0.221 & 0.216 & 0.219 & NS & 0.002 \\
\hline FFA, mg/100 g of SW & 1.05 & 1.93 & 1.43 & NS & 0.306 \\
\hline \multicolumn{6}{|l|}{ Cheese } \\
\hline Fat, \% & 33.50 & 33.58 & 33.23 & NS & 0.263 \\
\hline $\mathrm{FDB},{ }^{3} \%$ & 50.88 & 51.54 & 51.19 & NS & 0.357 \\
\hline $\mathrm{CP}, \%$ & 26.30 & 25.61 & 25.53 & NS & 0.325 \\
\hline $\mathrm{PDB},{ }^{4} \%$ & 39.95 & 39.31 & 39.34 & NS & 0.437 \\
\hline Moisture, \% & 34.16 & 34.85 & 35.09 & NS & 0.190 \\
\hline MNFS, ${ }^{5} \%$ & 51.37 & 52.47 & 52.56 & NS & 0.262 \\
\hline Salt, \% & 1.67 & 1.77 & 1.72 & NS & 0.032 \\
\hline Salt-in-the-moisture, $\%$ & 4.88 & 5.08 & 4.90 & NS & 0.069 \\
\hline Calcium, \% & 0.831 & 0.796 & 0.788 & NS & 0.008 \\
\hline Calcium/CP, \% & 3.16 & 3.11 & 3.09 & NS & 0.019 \\
\hline FFA, $\mathrm{mg} / 100 \mathrm{~g}$ of cheese & 15.47 & 16.07 & 18.83 & NS & 1.336 \\
\hline $\mathrm{pH}$ & 5.09 & 5.15 & 5.07 & NS & 0.031 \\
\hline
\end{tabular}

a,b,c Means within a row that do not share a common superscript differ $(P \leq 0.05)$.

${ }^{1} \mathrm{NPN}=$ Nonprotein nitrogen $\times 6.38$

${ }^{2}$ Whey protein $=[(\mathrm{CP}-\mathrm{NPN})-$ casein $]$.

${ }^{3} \mathrm{FDB}=$ Fat on a dry basis.

${ }^{4} \mathrm{PDB}=$ Protein on a dry basis.

${ }^{5} \mathrm{MNFS}=$ Moisture in the nonfat substance. 
Table 5. Adjusted mean $(\mathrm{n}=3$ ) milk solids, fat, CP, calcium, and FFA recoveries in whey, salt whey, and cheese in the manufacture of Cheddar cheeses from control, low, and high milk serum protein (SP) standardized milks.

\begin{tabular}{|c|c|c|c|c|c|}
\hline & \multicolumn{3}{|c|}{ Standardized milk } & \multirow[b]{2}{*}{ LSD } & \multirow[b]{2}{*}{ SEM } \\
\hline & Low SP & Control & High SP & & \\
\hline \multicolumn{6}{|c|}{ Milk solids recovery, \% } \\
\hline Whey & $48.84^{\mathrm{b}}$ & $51.33^{\mathrm{a}}$ & $52.03^{\mathrm{a}}$ & 1.022 & 0.260 \\
\hline Salt whey & 1.25 & 1.18 & 1.19 & NS & 0.175 \\
\hline Cheese & $50.05^{\mathrm{a}}$ & $47.45^{\mathrm{b}}$ & $46.73^{\mathrm{c}}$ & 0.524 & 0.133 \\
\hline \multicolumn{6}{|c|}{ Fat recovery, \% } \\
\hline Whey & $7.74^{\mathrm{b}}$ & $8.46^{\mathrm{a}}$ & $8.52^{\mathrm{a}}$ & 0.422 & 0.108 \\
\hline Salt whey & 0.60 & 1.06 & 0.86 & NS & 0.134 \\
\hline Cheese & $92.45^{\mathrm{a}}$ & $90.63^{\mathrm{b}}$ & $89.69^{b}$ & 1.359 & 0.346 \\
\hline \multicolumn{6}{|c|}{$\mathrm{CP}$ recovery, \% } \\
\hline Whey & $15.94^{\mathrm{c}}$ & $26.08^{\mathrm{b}}$ & $28.83^{\mathrm{a}}$ & 1.321 & 0.336 \\
\hline Salt whey & 0.51 & 0.59 & 0.62 & NS & 0.033 \\
\hline Cheese & $83.52^{\mathrm{a}}$ & $73.13^{\mathrm{b}}$ & $70.42^{\mathrm{c}}$ & 1.032 & 0.263 \\
\hline \multicolumn{6}{|c|}{ Calcium recovery, $\%$} \\
\hline Whey & $29.59^{b}$ & $32.87^{\mathrm{a}}$ & $33.60^{\mathrm{a}}$ & 1.682 & 0.428 \\
\hline Salt whey & 3.12 & 3.11 & 3.22 & NS & 0.119 \\
\hline Cheese & $66.18^{\mathrm{a}}$ & $64.61^{\mathrm{b}}$ & $63.70^{\mathrm{b}}$ & 1.191 & 0.303 \\
\hline \multicolumn{6}{|c|}{ FFA recovery, $\%$} \\
\hline Whey & 44.89 & 40.94 & 40.47 & NS & 1.513 \\
\hline Salt whey & 0.79 & 1.11 & 0.75 & NS & 0.210 \\
\hline Cheese & 64.92 & 51.39 & 54.75 & NS & 3.252 \\
\hline
\end{tabular}

${ }^{\mathrm{a}, \mathrm{b}, \mathrm{c}}$ Means within a row that do not share a common superscript differ $(P \leq 0.05)$.

using a cream separator) were used to standardize milk for cheese making instead of using unseparated whole milk. Neocleous et al. (2002a) reported a fat recovery of $91.74 \%$ in the cheese from standardized control milk. The fat recovery of $90.63 \%$ in the control cheese from standardized milk in the present study was consistent with Neocleous et al. (2002a). The Van Slyke and Barbano theoretical yield formulas predict a $93 \%$ fat recovery in the cheese. When milk was not separated, only pasteurized, before cheese manufacture in 3 previous studies in our laboratory, fat recoveries in Cheddar cheeses were $93.08 \%$ (Nelson et al., 2004a), 93.68 and 93.76\% (Barbano and Rasmussen, 1992), and 94.24\% (Lau et al., 1990). Manufacturing Cheddar cheese from milk with the low milk SP content may overcome some of the fat recovery issues caused by using a cream separator in milk standardization. The exact cause of the higher fat retention in the cheese of the low milk SP treatment is unclear. Although treatment means were not significantly different $(P>0.05)$, there was a higher mean CN-to-fat ratio in the low milk SP treatment standardized milk than in the control (Table 1). Few studies have been published concerning the effect of $\mathrm{CN}$-to-fat ratio on fat retention in Cheddar cheese; 2 abstracts were published and no consistent effect of CN-to-fat ratio was reported (Yiadom-Farkye and Ernstrom, 1985; Chen et al., 1996). The CN-to-fat ratios in standardized control milks of Neocleous et al. (2002a) and the present study were 0.68 and 0.72 , respectively.
The CN-to-fat ratios in standardized control milks of Nelson et al. (2004b), the 2 trials of Barbano and Rasmussen (1992), and Lau et al. (1990) were 0.66, 0.70, 0.69 , and 0.71 , respectively. There does not seem to be a trend of CN-to-fat ratio among these experiments that explains the fat recovery differences from standardized and nonstandardized milks. The influence of SP concentration on fat recovery may be explained by a more direct effect of milk SP on the surface-active proteins on the milk fat globules. In studies where milk (Peters, 1956; Breene et al., 1964) or cream (Metzger and Mistry, 1994) was homogenized before cheese making, the fat recovery was better than without homogenization. Homogenization causes $\mathrm{CN}$ micelles to associate with the surface of fat globules, the $\mathrm{CN}$ micelles participate in the matrix of $\mathrm{CN}$ formed by enzymatic coagulation, and the fat globules become attached to the matrix resulting in a decreased loss of fat into the whey. Even though the milk in the present study was not homogenized, it may be possible that because of higher $\mathrm{CN}$ as a percentage of true protein in the low milk SP treatment, there was more $\mathrm{CN}$ associated with the interface of the fat globules so that during coagulation more fat was held not just trapped in the CN matrix. These observations warrant further work.

Recovery of CP in the whey increased from the low milk SP treatment to the high milk SP treatment (Table $5)$. This trend was expected because the milk SP contents of the standardized milks followed the same trend 
(Table 1). The differences $(P \leq 0.05)$ in $\mathrm{CP}$ recovery in the cheese and whey among the treatments (Table 5) were consistent with differences $(P \leq 0.05)$ in $\mathrm{CN}$ as a percentage of true protein among the treatments (Table $1)$. We detected a lower $(P \leq 0.05)$ calcium and milk solids recovery in the whey and higher $(P \leq 0.05)$ calcium and milk solids recovery in the cheese for the low milk SP treatment than in the control or high milk SP treatment (Table 5). The low milk SP standardized milk contained more $(P \leq 0.05)$ calcium as a percentage of $\mathrm{CP}$ than did the control and high milk SP standardized milks (Table 1). More calcium as a percentage of CP in the standardized milk for cheese making (Table 1) would be expected to increase the calcium recovery in the cheese and decrease the calcium recovery in the whey and our results support this (Table 5).

There are no previous reports in the literature of a mass balance accounting for FFA in milk, whey, salt whey, and cheese. Analytical methods for measurement of FFA in milk, whey salt whey, and cheese are not as well developed as methods for measurement of other milk components. Therefore, the variation in total accountability for FFA (Table 5) was larger than for other milk components. Although no significant differences were detected $(P>0.05)$ among treatments in the present study, it is interesting to note the relative partitioning of milk FFA among whey, salt whey, and cheese. About 40 to $45 \%$ of the measured FFA from milk partitioned into the whey (Table 5). These are likely to be the shorter chain, more water-soluble FFA, and this has implications for flavor characteristics of whey products. The copper soap method of Melilli et al. (2004) that was used for FFA measurement in the present study has low recovery of short chain FFA (particularly C4) compared with GLC approaches (Melilli et al., 2004). Therefore, our estimates of the proportion of milk FFA partitioning in whey are probably conservative. Although the GLC method for FFA is more costly and labor intensive, it would be interesting to understand more about partitioning of individual FFA into whey as it relates to flavor and functional properties of whey.

The higher $(P \leq 0.05)$ adjusted cheese yield of the low SP treatment compared with the control and high SP treatments (Table 6) was mostly due to the higher fat recovery in the cheese (Table 5). The higher $(P \leq 0.05)$ cheese yield efficiencies of the low SP treatment were due to the higher fat recovery in the low SP cheese. Enhancement of fat recovery in cheese by removal of milk SP from milk before cheese making could be very important for the cheese industry and further work is needed to confirm this result.

\section{Aging and Proteolysis of Cheddar Cheese}

Titratable acidity, pH, and FFA. An increase in titratable acidity is highly correlated with an increase in cheese proteolysis during the aging of Cheddar cheese (Lau et al., 1991). A significant increase in the $\mathrm{pH}$ and titratable acidity with time of storage for cheeses of all treatments (Table 7) during $180 \mathrm{~d}$ of aging was observed (Figures 2 and 3). No significant $(P \leq 0.05)$ effect of milk SP concentration on cheese $\mathrm{pH}$ or FFA content of the cheese was detected (Table 7). There was a significant cheese age by treatment effect on cheese titratable acidity, but the differences among treatments did show a consistent trend after $30 \mathrm{~d}$ with increasing milk SP content (Figure 3). The FFA content of the cheeses ranged from about 7.5 to $22 \mathrm{mg}$ of FFA/100 g of cheese, which is very low compared with Italian-style cheeses, which, at the end of brine salting, can contain levels of $100 \mathrm{mg}$ of FFA (Melilli et al., 2004) and 600 mg of FFA $/ 100 \mathrm{~g}$ of cheese at $180 \mathrm{~d}$ (Licitra et al., 2000). Extraction and recovery of low levels of FFA in cheese is difficult, particularly with the copper soap method. Although the statistical analysis of our data in the present study showed a significant effect of the quadratic term for age (Table 7), we are not confident that these small systematic changes with age were due to processes within the cheese or to small but systematic changes in the performance of the copper soap method within our laboratory over the 180-d aging period. Variations in the extent of cheese dispersion during sample preparation for batches of cheeses analyzed at different times over the course of this study could certainly result in systematic variation of 10 to $20 \mathrm{mg}$ of FFA/ $100 \mathrm{~g}$ of cheese.

pH 4.6 and 12\% TCA SNPTN. All cheeses in the study increased in $\mathrm{pH} 4.6$ and $12 \%$ TCA SNPTN during the $180 \mathrm{~d}$ of refrigerated storage (Figure 4 ). There was a trend $(P<0.10)$ for a higher mean $\mathrm{pH} 4.6$ SNPTN content of the low milk SP treatment (Table 7; Figure 4) than in both the control and high milk SP treatments. Primary proteolysis (measured by $\mathrm{pH} 4.6$ SNPTN) may have been higher in the low milk SP cheeses compared with control and high milk SP cheeses because the amount of chymosin and plasmin inhibitors in the cheese were lower in the low milk SP cheeses. The milk SP content of the high milk SP treatment in our study was much less than if the milk would have been concentrated $2 \times$ in using UF. No difference $(P>0.05)$ in $12 \%$ TCA SNPTN was detected due to milk SP content. Therefore, no effect of milk SP on the bacterial enzymes responsible for secondary proteolysis and $12 \%$ TCA soluble nitrogen was detected in our experiment in $180 \mathrm{~d}$ of aging. Neocleous et al. (2002b) reported a lower $12 \%$ TCA SNPTN with an increase in milk concentration factor. This result may have been due to the increasing immunoglobulin concentration with increasing concentration factor in the study of Neocleous et al. (2002b). 
Table 6. Mean $(n=3)$ actual, moisture and salt-adjusted, Van Slyke and Barbano theoretical cheese yields and cheese yield efficiencies for Cheddar cheeses manufactured from low, control and high milk serum protein (SP) standardized milks.

\begin{tabular}{|c|c|c|c|c|c|}
\hline & \multicolumn{3}{|c|}{ Standardized milk } & \multirow[b]{2}{*}{ LSD } & \multirow[b]{2}{*}{ SEM } \\
\hline & Low SP & Control & High SP & & \\
\hline & 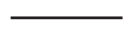 & eese/100 & & & \\
\hline \multicolumn{6}{|l|}{ Yield } \\
\hline Actual & 9.06 & 8.91 & 8.84 & NS & 0.050 \\
\hline Adjusted $^{1}$ & $9.45^{\mathrm{a}}$ & $9.18^{b}$ & $9.08^{b}$ & 0.206 & 0.052 \\
\hline Van Slyke & 9.52 & 9.45 & 9.36 & $\mathrm{NA}^{2}$ & NA \\
\hline Barbano & 9.51 & 9.45 & 9.36 & NA & NA \\
\hline \multicolumn{6}{|c|}{ Yield efficiency ${ }^{3}$} \\
\hline Van Slyke & $99.25^{\mathrm{a}}$ & $97.14^{\mathrm{b}}$ & $97.10^{\mathrm{b}}$ & 0.832 & 0.212 \\
\hline Barbano & $99.38^{\mathrm{a}}$ & $97.11^{b}$ & $97.01^{b}$ & 0.859 & 0.219 \\
\hline
\end{tabular}

${ }^{\mathrm{a}, \mathrm{b}}$ Means within a row that do not share a common superscript differ $(P \leq 0.05)$.

${ }^{1}$ Moisture adjusted to $37 \%$ and salt to $1.5 \%$.

${ }^{2} \mathrm{NA}=$ Not applicable.

${ }^{3}$ Yield efficiency $=$ adjusted yield divided by theoretical yield .

It is important to distinguish between the MF process and cheese manufacture used in this study (where the concentration factor of $\mathrm{CN}$ in the cheese milk was $1 \times$ for all treatments) from the more typical use of MF reported by Neocleous et al. (2002b). Neocleous et al. (2002b) used low concentration factor (1.2 to $1.8 \times$ ) RMF for cheese manufacture. In that study, (Neocleous et al., 2002b), milk SP concentration in the milk for cheese making was about the same as control milk, but the large molecular weight proteins (e.g., immunoglobulins) would have been more concentrated (1.2 to $1.8 \times$ ) in the RMF than in control milk (Jost et al., 1999). In our study, not only did we have less milk SP in the low milk SP treatment than in typical milk, but also by diluting the RMF with permeate from ultrafiltration, we kept the large molecular weight proteins at the concentration found in control milk. The implications of these differences are that in the present study, the influence of large molecular weight inhibitors of chymosin and plasmin, such as $\alpha_{2}$-macroglobulin (Akaeda et al., 1971; Lelievre et al., 1990) and $\alpha_{2}$-antiplasmin (Steiner et al., 1987; Precetti et al., 1997), respectively, was the same in all treatments because there was no difference in concentration factor of the milks.

Electrophoresis. Casein proteolysis measured by densitometry of SDS-PAGE gels was reported as ratios of $\alpha_{\mathrm{s}}-\mathrm{CN}$ :para- $\kappa-\mathrm{CN}$ and $\beta-\mathrm{CN}$ :para- $\kappa-\mathrm{CN}$ and was influenced by milk SP content (Figure 5 and Table 7). As para- $\kappa-\mathrm{CN}$ ratio decreases, proteolysis increases. In the primary phase of proteolysis during Cheddar cheese

Table 7. Type III sums of squares and degrees of freedom for ANOVA of $\mathrm{pH}$, titratable acidity (TA), soluble nitrogen as a percentage of total nitrogen (SNPTN), FFA, $\alpha_{\mathrm{s}}-\mathrm{CN}$ :para- $\kappa$-CN ratio, and $\beta$-CN:para- $\kappa-\mathrm{CN}$ ratio.

\begin{tabular}{|c|c|c|c|c|c|c|c|c|}
\hline & $\mathrm{df}$ & $\mathrm{pH}$ & TA & FFA & $\begin{array}{l}\mathrm{pH} 4.6 \\
\text { SNPTN }\end{array}$ & $\begin{array}{l}12 \% \text { TCA } \\
\text { SNPTN }\end{array}$ & $\begin{array}{l}\alpha_{\mathrm{s}}-\mathrm{CN}: \\
\text { para- } \kappa-\mathrm{CN}\end{array}$ & $\begin{array}{l}\beta-\mathrm{CN}: \\
\text { para- } \kappa-\mathrm{CN}\end{array}$ \\
\hline \multicolumn{9}{|l|}{ Whole plot } \\
\hline Treatment $^{1}(\mathrm{~T})$ & 2 & 0.06 & 0.01 & 27.23 & $5.15 \dagger$ & 1.32 & $0.64 * *$ & $1.52^{* *}$ \\
\hline Replicate (R) & 2 & 0.07 & 0.03 & 0.87 & 1.48 & 0.05 & $0.19 *$ & 0.01 \\
\hline $\mathrm{T} \times \mathrm{R}^{2}$ & 4 & $0.05^{* *}$ & 0.02 & 15.61 & $2.38 \dagger$ & $2.38^{*}$ & 0.06 & 0.17 \\
\hline \multicolumn{9}{|l|}{ Sub-plot } \\
\hline Age & 1 & $0.12^{* *}$ & $0.57 * *$ & 16.97 & $1132.48^{* *}$ & $420.42 * *$ & $31.88^{* *}$ & $2.64 * *$ \\
\hline Age $\times$ Age & 1 & $0.03^{* *}$ & $0.04 * *$ & $514.70^{* *}$ & $58.84^{* *}$ & $10.54^{* *}$ & $4.81 * *$ & $0.09 \dagger$ \\
\hline Age $\times \mathrm{T}$ & 2 & - & $0.03 *$ & - & $2.09 *$ & - & - & - \\
\hline Error & 23 & - & 0.11 & - & 5.99 & - & - & - \\
\hline Error & 25 & 0.05 & - & 170.40 & - & 5.38 & 1.08 & 0.64 \\
\hline $\mathrm{R}$-squared & & 0.85 & 0.87 & 0.78 & 0.99 & 0.99 & 0.97 & 0.87 \\
\hline
\end{tabular}

${ }^{1}$ Treatments are cheeses manufactured from milk with $0.18,0.52$, and $0.63 \%$ serum proteins.

${ }^{2}$ Whole plot error $=\mathrm{T} \times \mathrm{R}$.

$\dagger P \leq 0.10 ; * P \leq 0.05 ; * * P \leq 0.01$. 


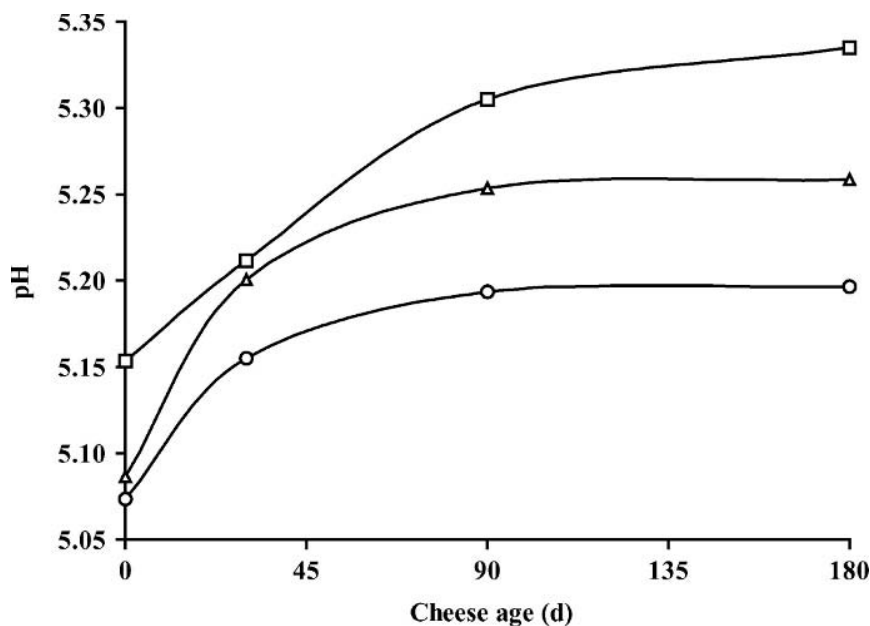

Figure 2. Mean $(\mathrm{n}=3) \mathrm{pH}\left(25^{\circ} \mathrm{C}\right)$ of treatment and control cheeses during aging. Cheeses were made from milk with differing amounts of serum proteins, $0.18 \%$ (triangles), $0.52 \%$ (squares), and $0.63 \%$ (circles).

aging, most of the proteolysis is carried out by chymosin and to a lesser degree by plasmin (Grappin et al., 1985). The low milk SP treatment had a lower $\alpha_{\mathrm{s}}-\mathrm{CN}$ :para- $\kappa$ $\mathrm{CN}$ and $\beta-\mathrm{CN}$ :para- $\kappa-\mathrm{CN}$ ratio at the time of removal from the press ( $17 \mathrm{~h}$ after cheese making) indicating greater proteolysis even before refrigerated storage of the cheese (Figure 5). With respect to the high $\beta$-CN proteolysis (Figure 5) soon after cheese making, one might presume that the cheeses of the low milk SP treatment were bitter. The investigators subjectively evaluated the cheeses in this study and found that at

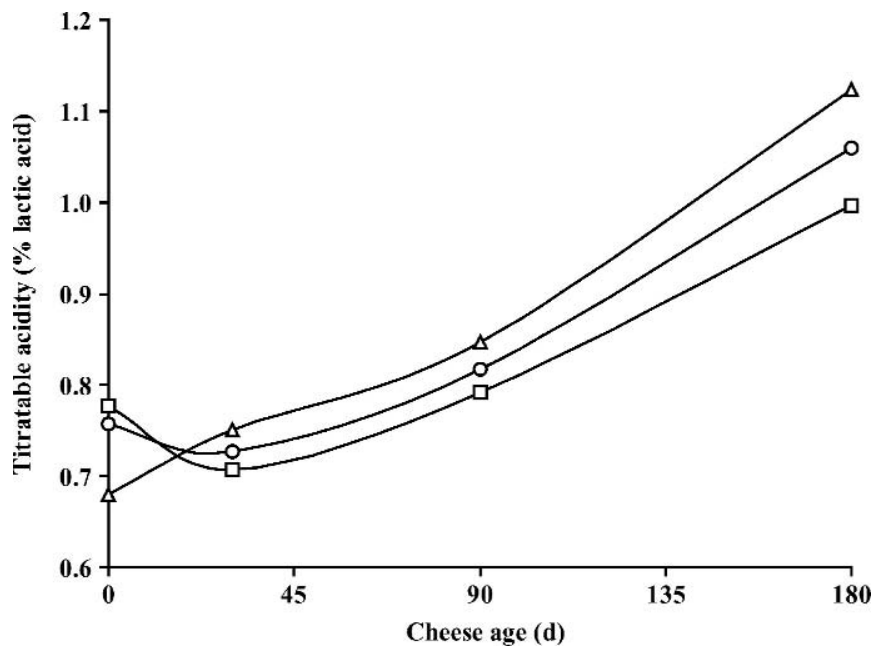

Figure 3. Mean $(\mathrm{n}=3)$ titratable acidity of treatment and control cheeses during aging. Cheeses were made from milk with differing amounts of serum proteins, $0.18 \%$ (triangles), $0.52 \%$ (squares), and $0.63 \%$ (circles).

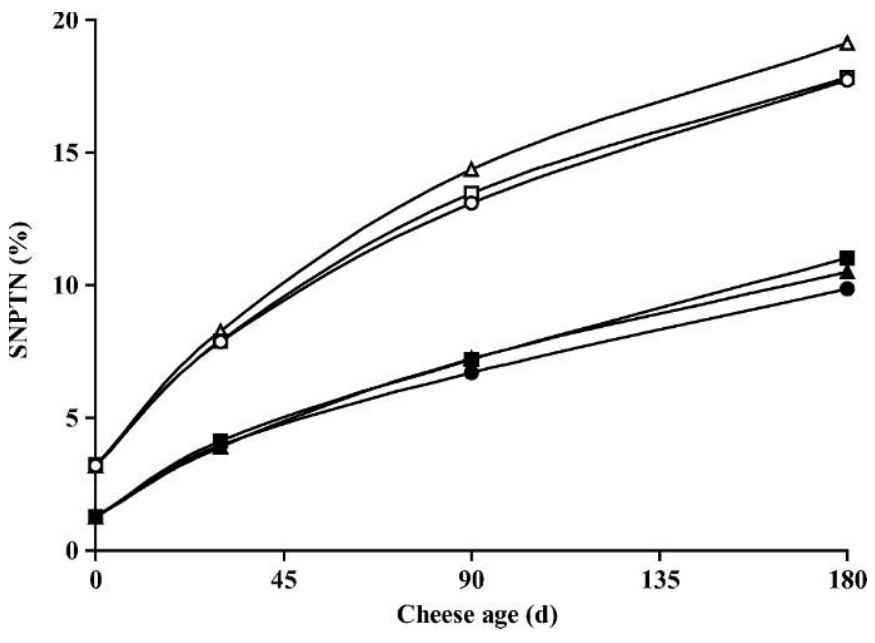

Figure 4. Mean (n = 3) pH 4.6 (open symbols) and 12\% TCA (solid symbols) soluble nitrogen as a percentage of total nitrogen (SNPTN) of treatment and control cheeses during aging. Cheeses were made from milk with differing amounts of serum proteins, $0.18 \%$ (triangles), $0.52 \%$ (squares), and $0.63 \%$ (circles).

no time during aging did bitterness develop. The milk conditions before cheese making may have been more favorable for plasmin activity in the low milk SP retentate than the other treatments. If the large difference in $\beta$-CN:para- $\kappa$-CN ratio at $d 0$ of the low milk SP treatment was due wholly or in part to plasmin activity, it would occur before the $\mathrm{pH}$ dropped to the final cheese $\mathrm{pH}$. From our data, we cannot be certain that the differences in CN proteolysis (Figure 5) occurred during cheese manufacture or before cheese manufacture during overnight storage of the retentate at $4^{\circ} \mathrm{C}$. Plasmin would be active during the $\mathrm{MF}$ processing at $50^{\circ} \mathrm{C}$ and

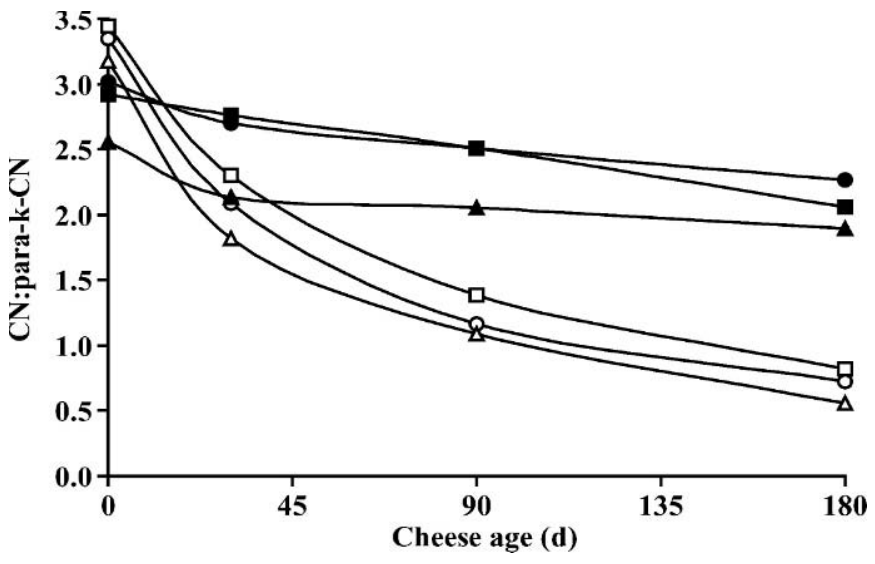

Figure 5. Mean $(\mathrm{n}=3) \alpha_{\mathrm{s}}-\mathrm{CN}$ :para- $\kappa-\mathrm{CN}$ ratio (open symbols) and $\beta$-CN:para- $\kappa-\mathrm{CN}$ ratio (closed symbols) of treatment and control cheeses during aging measured using SDS-PAGE. Cheeses were made from milk with differing amounts of serum proteins, $0.18 \%$ (triangles), $0.52 \%$ (squares), and $0.63 \%$ (circles). 
refrigerated storage $4^{\circ} \mathrm{C}$, and during cheese making at 31 to $38^{\circ} \mathrm{C}$. However, in the SDS-PAGE gel (Figure 1), there was not evidence of more proteolysis in the low milk SP standardized milk.

Because chymosin is the dominant protease in Cheddar cheese, the increased CN proteolysis (Table 7; Figure 5) in the low milk SP cheese was likely due to a lack of chymosin's inhibitors in the cheese. In Cheddar cheeses made from milk concentrated $5 \times$ using UF, Creamer (1987) attributed the lower $\alpha_{\mathrm{s} 1}-\mathrm{CN}$ proteolysis to rennet inhibition by whey proteins. Creamer et al. (1985) reported a much higher $\alpha_{\mathrm{s} 1}-\mathrm{CN}$ degradation with higher chymosin activity in the cheese than $\beta$-CN. However, in an environment like that of the low milk SP cheese, the action of chymosin may be different than in the control cheese especially at the temperature during pressing $\left(25\right.$ to $\left.27^{\circ} \mathrm{C}\right)$. Conditions in cheese (e.g., $\mathrm{pH}$ ) are closer optimal for an acid protease, chymosin, than an alkaline protease, plasmin. Lelievre et al. (1990) reported that the high molar mass fraction of whey protein concentrate, consisting mostly of immunoglobulins, was more inhibitory to the coagulation of milk than the lower molar mass fraction (i.e., $\alpha$-LA). More work should be done to determine if immunoglobulins are more potent inhibitors of proteolysis in cheese than other milk SP.

\section{CONCLUSIONS}

The standardized milk for cheese making of the low milk SP treatment contained more $\mathrm{CN}$ as a percentage of true protein and more calcium as a percentage of crude protein, whereas the NPN and total calcium content was not different from the control and high SP treatments. The low milk SP milk contained less FFA than the control and high milk SP treatment, but no differences in FFA content of the cheeses was detected. Approximately 40 to $45 \%$ of the FFA found in the milk before cheese making was lost into the whey during cheese making. Decreasing the milk SP content of milk by $65 \%$ and increasing by $21 \%$ did not significantly influence general Cheddar cheese composition. Higher fat recovery in the cheeses and higher cheese yield of the low milk SP treatment were not expected and may be due to an increase association of CN micelles with milk fat globules when milk SP concentration is low. There was more proteolysis in the low milk SP cheese and this may be due to the lower concentration of undenatured $\beta$-LG, $\alpha$-LA, and other higher molecular weight milk SP retained in the cheeses made from milk with low milk SP content.

\section{ACKNOWLEDGMENTS}

The authors thank Tom Burke, Maureen Chapman, Bonnie Coffin, Mark Elwell, Kerry Kalegian, Bob Kal- taler, Laura Landolf, and Joanna Lynch for assistance, and the Northeast Dairy Foods Research Center and Dairy Management Inc. (Rosemont, IL) for partial financial support.

\section{REFERENCES}

Akaeda, H., H. Miura, and M. Mikami. 1971. Studies on the rennin inhibitor in serum. Part II. Inhibiting action on rennin coagulation by $\alpha_{2}$-macroglobulin. J. Agric. Chem. Soc. Japan. 45:449-453.

AOAC. 2000. Official Methods of Analysis. 17th ed. Association of Official Analytical Chemists, Gaithersburg, MD.

Barbano, D. M., and R. R. Rasmussen. 1992. Cheese yield performance of fermentation-produced chymosin and other coagulants. J. Dairy Sci. 75:1-12.

Bastian, E. D., K. G. Hansen, and R. J. Brown. 1993. Inhibition of plasmin by $\beta$-lactoglobulin using casein and a synthetic substrate. J. Dairy Sci. 76:3354-3361.

Breene, W. M., W. V. Price, and C. A. Ernstrom. 1964. Manufacture of pizza cheese without starter. J. Dairy Sci. 47:1173-1180.

Bynum, D. G., and D. M. Barbano. 1985. Whole milk reverse osmosis retentates for Cheddar cheese manufacture: Chemical changes during aging. J. Dairy Sci. 68:1-10.

Chen, C. M., D. D. Bogenrief, and M. E. Johnson. 1996. Effect of casein to fat ratio on stirred curd Cheddar cheese yield. J. Dairy Sci. 79(Suppl. 1):94. (Abstr.)

Covacevich, H. R., and F. V. Kosikowski. 1978. Mozzarella and Cheddar cheeses manufactured by ultrafiltration principles. J. Dairy Sci. 61:701-709.

Creamer, L. K. 1987. Effect of various levels of rennet addition on characteristics of Cheddar cheese made from ultrafiltered milk. N.Z. J. Dairy Sci. and Technol. 22:205-214.

Creamer, L. K., R. C. Lawrence, and J. Gilles. 1985. Effect of acidification of cheese milk on the resultant Cheddar cheese. N.Z. J. Dairy Sci. Technol. 20:185-203.

Glantz, S. A., and B. K. Slinker. 2001. Multicollinearity and what to do about it. Pages 185-187 in Primer of Applied Regression and Analysis of Variance, 2nd ed. McGraw-Hill, Inc., New York, NY.

Grappin, R., T. C. Rank, and N. F. Olson. 1985. Primary proteolysis of cheese proteins during ripening. A review. J. Dairy Sci. 68:531-540.

Jost, R. R., R. Brandsma, and S. Rizvi. 1999. Protein composition of micellar casein obtained by cross-flow micro-filtration of skimmed milk. Int. Dairy J. 9:389-390.

Lau, K. Y., D. M. Barbano, and R. R. Rasmussen. 1990. Influence of pasteurization on fat and nitrogen recoveries and Cheddar cheese yield. J. Dairy Sci. 73:561-570.

Lau, K. Y., D. M. Barbano, and R. R. Rasmussen. 1991. Influence of pasteurization of milk on protein breakdown in Cheddar cheese during aging. J. Dairy Sci. 74:727-740.

Lelievre, J., L. K. Creamer, and K. L. Tate. 1990. Inhibition of calf vell and microbial rennet action by whey protein concentrate. Milchwissenschaft 45:71-75.

Licitra, G., P. Campo, M. Manenti, G. Protelli, S. Scuderi, S. Carpino, and D. M. Barbano. 2000. Composition of Ragusano cheese during aging. J. Dairy Sci. 83:404-411.

Lo, C. G., and E. D. Bastian. 1997. Chymosin activity against $\alpha_{\mathrm{s} 1}$ casein in model systems: Influence of whey proteins. J. Dairy Sci. 80:615-619.

Lynch, J. M., D. M. Barbano, and J. R. Fleming. 2002. Determination of the total nitrogen content of hard, semihard and processed cheese by the Kjeldahl method: Collaborative study. J. AOAC 85:445-455.

Ma, Y., D. M. Barbano, and M. Santos. 2003. Effect of $\mathrm{CO}_{2}$ addition to raw milk on proteolysis and lipolysis at $4^{\circ} \mathrm{C}$. J. Dairy Sci. 86:1616-1631.

Melilli, C., D. M. Barbano, M. Manenti, J. M. Lynch, S. Carpino, and G. Licitra. 2004. Lipolysis and proteolysis in Ragusano cheese during brine salting at different temperatures. J. Dairy Sci. 87:2359-2374. 
Metzger, L. E., D. M. Barbano, M. A. Rudan, and P. S. Kindstedt. 2000. Effect of milk preacidification on low fat Mozzarella cheese. I. Composition and yield. J. Dairy Sci. 83:648-658.

Metzger, L. E., and V. V. Mistry. 1994. A new approach using homogenization of cream in the manufacture of reduced fat cheddar cheese. 1. Manufacture, composition, and yield. J. Dairy Sci. 77:3506-3515.

Nelson, B. K., and D. M. Barbano. 2005. A microfiltration process to maximize removal of serum protein from skim milk prior to cheese making. J. Dairy Sci. 88:1891-1900.

Nelson, B. K., J. M. Lynch, and D. M. Barbano. 2004a. Impact of milk preacidfication with $\mathrm{CO}_{2}$ on Cheddar cheese composition and yield. J. Dairy Sci. 87:3581-3589.

Nelson, B. K., J. M. Lynch, and D. M. Barbano. 2004b. Impact of milk preacidification with $\mathrm{CO}_{2}$ on the aging and proteolysis of Cheddar cheese. J. Dairy Sci. 87:3590-3600.

Neocleous, M., D. M. Barbano, and M. A. Rudan. 2002a. Impact of low concentration factor microfiltration on milk component recovery and Cheddar cheese yield. J. Dairy Sci. 85:2415-2424.

Neocleous, M., D. M. Barbano, and M. A. Rudan. 2002b. Impact of low concentration factor microfiltration on composition and aging of Cheddar cheese. J. Dairy Sci. 85:2425-2437.

O'Keeffe, A. M., P. F. Fox, and C. Daly. 1978. Proteolysis in Cheddar cheese: Role of coagulant and starter bacteria. J. Dairy Res. 45:465-477.
Pérez, M. D., C. D. de Villegas, L. Sánchez, P. Aranda, J. M. Ena, and M. Calvo. 1989. Interaction of fatty acids with $\alpha$-lactoglobulin and albumin from ruminant milk. J. Biochem. 106:1094-1097.

Peters, I. I. 1956. Cheddar cheese made from pasteurized milk homogenized at various pressures. J. Dairy Sci. 39:1083-1088.

Precetti, A. S., M. P. Oria, and S. S. Nielsen. 1997. Presence in bovine milk of two protease inhibitors of the plasmin system. J. Dairy Sci. 80:1490-1496.

Steiner, J. P., M. Migliorini, and D. K. Strickland. 1987. Characterization of the reaction of plasmin with $\alpha 2$-macroglobulin. Biochemistry 26:8487-8495.

Verdi, R. J., D. M. Barbano, and M. E. Dellavalle. 1987. Variability in true protein, casein, nonprotein nitrogen, and proteolysis in high and low somatic cell milks J. Dairy Sci. 70:230-242.

Walstra, P., T. J. Geurts, A. Noomen, A. Jellema, and M. A. J. S. van Boekel. 1999. Page 7 in Dairy Technology: Principles of Milk Properties and Processes. Marcel Dekker, Inc., New York, NY.

Wehr, M. H., and J. F. Frank, ed. 2004. Standard Methods for the Examination of Dairy Products. 17th ed. Am. Publ. Health Assoc., Inc., Washington, DC.

Yiadom-Farkye, N. A., and C. A. Ernstrom. 1985. Effect of caseinfat ratio in milk on fat recovery in Cheddar cheese. J. Dairy Sci. 68(Suppl. 1):54-55. 